\title{
Pregnancy diagnosis in goat by using vaginal cytology and trans-abdominal ultrasonography
}

\author{
Md. Aziz Ali, Md. Faruk Islam, S M Latifur Rahman and Begum Fatema Zohara* \\ Department of Medicine, Surgery and Obstetrics, Faculty of Veterinary and Animal Science, Hajee Mohammad Danesh \\ Science and Technology University, Basherhat, Dinajpur-5200, Bangladesh
}

Received August 27, 2020

Revised September 18, 2020

Accepted September 18, 2020

\section{*Correspondence}

Begum Fatema Zohara

E-mail: begumfatemafatema@ymail.com

ORCID

https://orcid.org/0000-0002-4101-5036

\begin{abstract}
The present study was conducted in a goat farm for pregnancy diagnosis by using vaginal cytology and B-mode real time ultrasound using $5 \mathrm{MHz}$ probe by transabdominal method. Seventeen pregnant does were used for this study. The objective of the study was to determine the earliest day of pregnancy and describe the chronological characteristics of pregnancy from day 22 to day 40 for vaginal cytology and day 25 to day 60 for ultrasonography of gestation. The differences among the average percentage of cell value in different age of pregnancy were significant $(p<0.05)$. The average percentage of intermediate cells $(81.12 \%)$ was also significantly $(p<0.05)$ higher than superficial $(9.41 \%)$, keratinized $(7.10 \%)$ and neutrophil $(2.61 \%)$ on $22-40$ th days of pregnancy. In case of real time B-mode ultrasonography, the gestational sac was observed only in three does out of seventeen (17.6\%) at 25-30 days whereas the placentomes and heart beat of the foetus were first detected at 31-35 days in six does (35.3\%). The foetal leg buds were first visualized at 36-40 days in four does (23.5\%) whereas the foetal vertebral column was first observed at 36-40 days of gestation in only three does (17.6\%). In conclusion, vaginal cytology and trans-abdominal ultrasonography can be used for detection of early pregnancy in does.
\end{abstract}

Keywords: does, pregnancy diagnosis, trans-abdominal ultrasonography, vaginal cytology

\section{INTRODUCTION}

Bangladesh has a subtropical monsoon climate characterized by wide seasonal variations in rainfall, moderately warm temperatures, and high humidity. Bangladesh lies in the North-Eastern part of South Asia between $20.02^{\circ}$ and $26.038^{\circ}$ north latitude and $88.001^{\circ}$ and $92.041^{\circ}$ east longitude. The goats of Bangladesh usually show estrus across the year with no anovulatory period. Bangladesh has the second highest population of goat among the Asiatic countries which accounts for about 60.60 million heads representing $57 \%$ of total ruminant livestock (Faostat et al., 2009). The intensive goat production and the wide spread application of the controlled breeding techniques, such as artificial insemination increased the need for an accurate early pregnancy diagnosis. The pregnancy diagnosis in goats is essential for better efficacy and management of reproduction (Doize et al., 1997), providing information about conception rates after artificial insemination (Matsas et al., 2007), gestation course (Ameret al., 2010), time for drying-off and parturition date (Doize et al., 1997; González et al., 2004). The utilization of an accurate and easily applicable method for pregnancy diagnosis allows the timely repeated insemination, breeding or culling of non-pregnant animals (Ameret al., 2010). A number of techniques for pregnancy diagnosis have been 
implemented; some of them are efficient and applicable under field condition, but not enough accurate. Several investigation were carried out during early pregnancy in the Black Bengal breed of goat (Talukder et al., 2020). Trans-abdominal ultrasonography (Gonalez et al., 2004) and vaginal cytology are a simple technique that can be used by practitioners for pregnancy diagnosis in goat (Sharma and Sharman et al., 2016).

In Bangladesh, most of the goats are bred by natural service and are generally unobserved or unrecorded making fertile breeding impossible to determine early detection of pregnancy. Pregnancy diagnosis is depending mainly on the non-return to estrous after service. However, recently some researchers have been taken initiative to diagnosis the pregnancy in large and small ruminants by using ultrasonography. Thus, the present work was performed to determine the pregnancy by using vaginal cytology, to determine the earliest stage of pregnancy using trans-abdominal ultrasonography and to assess the chronological changes of the foetal development in the pregnant does at different gestation period that not being studied before in does in Bangladesh.

\section{MATERIALS AND METHODS}

\section{Study area and period}

The study was carried out on a goat farm located at $\mathrm{Pa}-$ harpur in Dinajpur under the supervision of Department of Medicine, Surgery and Obstetrics, Hajee Mohammad Danesh Science and Technology University (HSTU), Dinajpur. The research units are located on $25.38^{\circ} \mathrm{N}$ latitude and $88.41^{\circ} \mathrm{E}$ longitude, respectively and elevated $37.5 \mathrm{~m}$ above sea level. The area receives on average $170 \mathrm{~mm}$ of rainfall. Mean annual minimum and maximum temperatures experienced at the site are 33.5 and $10.5^{\circ} \mathrm{C}$, respectively. The study was conducted between December' 2017 to April' 2018.

\section{Experimental animals and management}

A total of 17 clinically healthy does of 2.5-3 years old and $22-25 \mathrm{~kg}$ body weight were used for this study. The does were maintained on natural grazing along with concentrate mixture (25\% crushed maize, 50\% wheat bran, $20 \%$ soybean meal, $1 \%$ fish meal, $2 \%$ DCP powder, $1.5 \%$ salt and $0.5 \%$ vitamin-mineral premix) during the experimental period. Water was supplied ad libitum.

\section{Oestrous detection}

Estrous detection in does was carried out twice a day for $1 \mathrm{~h}$ period by observing clinical signs. All goats were naturally mated during heat according to the routine program adapted in the farm. Expectation of early pregnancy was done by non-return to oestrus (>17-21 days).

\section{Vaginal cytology of pregnant does}

For determining the early pregnancy stage vaginal smear was collected from the pregnant does with the aid of vaginal swabs. At the anterior vagina, the swab was gently and briskly rolled against the vaginal mucosa and carefully withdrawn. The swab was immediately smeared on a warm glass slide, air dried and immediately fixed with $100 \%$ ethanol. The smears were stained with Giemsa stain (Zohara et al., 2014). The cells encountered in the vaginal smear were categorized as percentage of superficial, parabasal, and intermediate cells, and leucocytes. Identification of vaginal epithelial cells was performed by microscopic observation $(\times 100)$. The percentage of vaginal cells was calculated as the number of each type of cell divided by the total number of cells seen within 3 microscopic fields.

\section{Real-time, B-mode ultrasonography}

A real time B-mode ultrasound scanner equipped with a $5 \mathrm{MHz}$ sector probe (DRAMINSKI ANIMAL proti portable ultrasound scanner, Poland) was used for scanning. Scanning was performed after shaving the inguinal region, in front and on either side of udder of the animal. The animal was lightly restrained by one person in standing position and also in dorsal recumbent position. One of the hind legs of the does was folded up at the time of scanning for proper placement of the probe. An ultrasound coupling gel was applied in each time to the probe to develop good contact and to remove air between probe and animal skin. Each animal was subjected to scanning for at least five minutes at different days (days 25-30, 31$35,36-40,41-45,46-50,51-55$ and 56-60).

\section{Statistical analysis}

The data were recorded and analyzed statistically by using software SPSS (Version 20.0). Chi-square test was performed and the results were expressed in percentage with $p$-value and significance was determined $(p<0.05)$. 


\section{RESULTS}

The study was conducted in a small scale goat farm located at Paharpur in Dinajpur. The purpose of this study was to diagnose the pregnancy by using vaginal cytology and real time B-mode ultrasonography $(5 \mathrm{MHz})$.

\section{Vaginal cytology}

During the study, a total of 5 types of vaginal cells were identified and illustrated in figures (Fig. 1A-D). Parabasal (p) cells were small, round or nearly round and had a high nuclear to cytoplasm ratio, oval shape with large, prominent nuclei or polygonal shape with a small nuclear/cytoplasmic ratio were intermediate (i) cells. The Neutrophils (n) were the little ones with segmented nuclei. Polygonal in shape and distinctly flat, with pyknotic nuclei (very small and dark) were superficial (s) cells. Normal bacterial flora was present and organisms often were attached to the superficial cells.

The percentages of vaginal epithelial cells according to different days of gestation length are presented in Table 1. Cell counts increased sharply after 21 days of gestation and clumping of the intermediate and superficial cells increased in the following days (Fig. 1E). The average percentages of intermediate cells during early stage of pregnancy were $78.84 \%$ at $22-25$ days, $84.15 \%$ at $26-30$ days, $81.73 \%$ at $31-35$ days and $79.74 \%$ at $36-40$ days. The average percentage of superficial cells and the keratinized cells were $9.61 \%, 7.76 \%, 9.90 \%, 10.35 \%$ and $6.87 \%, 5.64 \%$, $7.34 \%, 8.54 \%$ respectively on the similar days. The para-
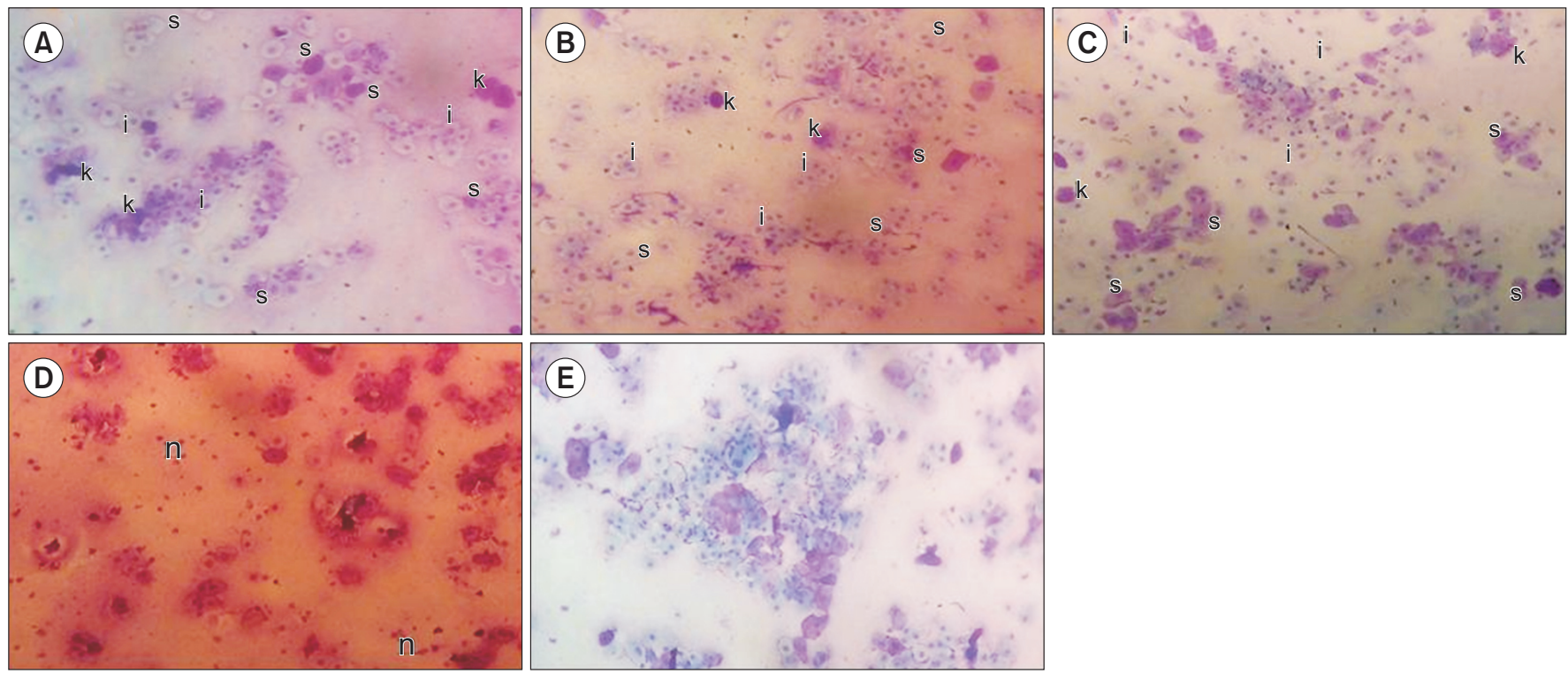

Fig. 1. Photomicrographs of exfoliative vagina cells during various days of the gestation period of does (A: smear of day 24, B: smear of day 29, C: smear of day 33, D: smear of day 39, E: clumping of the cells). Name of the vaginal epithelial cells shown as, intermediate (i), superficial (s), keratinized (k) and neutrophil (n).

Table 1. Percentage of different exfoliative cells of vaginal smears in early stages of pregnancy in does

\begin{tabular}{|c|c|c|c|c|c|}
\hline $\begin{array}{c}\text { Gestation length } \\
\text { (days) }\end{array}$ & \multicolumn{5}{|c|}{ Average percentage of vaginal cells } \\
\hline $26-30$ & 0 & $84.15^{\mathrm{Aa}}$ & $7.76^{\mathrm{Bb}}$ & $5.64^{\mathrm{Bc}}$ & $2.45^{\mathrm{Cd}}$ \\
\hline $31-35$ & 0 & $81.73^{\mathrm{Aa}}$ & $9.90^{\mathrm{Bb}}$ & $7.34^{\mathrm{Bc}}$ & $1.95^{\mathrm{Cd}}$ \\
\hline
\end{tabular}

\footnotetext{
${ }^{A-C}$ superscripts in a row indicate statistically significant difference $(p<0.05)$.

${ }^{a-c}$ superscripts in a column indicate statistically insignificant difference $(p>0.05)$.
} 
basal cells were absent during the early stages of pregnancy. The differences among the average percentage of cell value in different age of pregnancy were significant $(p<0.05)$. The average percentage of intermediate cells $(81.12 \%)$ was also significantly $(p<0.05)$ higher than superficial (9.41\%), keratinized (7.10\%) and neutrophil (2.61\%) on 22-40 days of pregnancy.

\section{Findings of real-time, B-mode ultrasonography in pregnant does}

The present study was conducted to diagnose pregnancy in does using the real time B-mode ultrasonography by taking the following criteria or chronological changes.

\section{Gestational sac}

In the present study, gestational sac was detected be-

Table 2. Percentage of pregnant does based on observation of gestational sac

\begin{tabular}{cccc}
\hline $\begin{array}{c}\text { Days after } \\
\text { mating }\end{array}$ & $\begin{array}{c}\text { Gestational sac } \\
\text { observed }\end{array}$ & $\begin{array}{c}\text { Gestational sac } \\
\text { not observed }\end{array}$ & Total \\
\hline $25-30$ & $17.6 \%(3)$ & $82.4 \%(14)$ & 17 \\
$31-35$ & $100 \%(17)$ & $0 \%(0)$ & 17 \\
$36-40$ & $100 \%(17)$ & $0 \%(0)$ & 17 \\
$41-45$ & $100 \%(17)$ & $0 \%(0)$ & 17 \\
$46-50$ & $100 \%(17)$ & $0 \%(0)$ & 17 \\
$51-55$ & $100 \%(17)$ & $0 \%(0)$ & 17 \\
$56-60$ & $100 \%(17)$ & $0 \%(0)$ & 17 \\
\hline
\end{tabular}

tween 25-30 days in 3 out of 17 does with the accuracy of $17.6 \%$. The presence of anechoic areas cranial to the bladder was considered as positive for pregnancy (Table 2 and Fig. 2).

\section{Heart beat}

In the present investigation the heart beat was detected for the first time at 31-35 days with accuracy of $35.3 \%$. The heart beat became more prominent with the advancement of gestation and the rate of accuracy was 58.8 , 88.2 and $100 \%$ at $36-40,41-45$ and $46-50$ days after mating, respectively (Table 3).

\section{Placentomes}

No placentome was detected at 25-30 days after the mating. But, it was detected only in six does (35.3\%) as small circular, concave structures between $31-35$ days of

Table 3. Percentage of pregnant does based on foetal heart beat

\begin{tabular}{cccc}
\hline $\begin{array}{c}\text { Days after } \\
\text { mating }\end{array}$ & $\begin{array}{c}\text { Heart beat } \\
\text { observed }\end{array}$ & $\begin{array}{c}\text { Heart beat } \\
\text { not observed }\end{array}$ & Total \\
\hline $25-30$ & $0 \%(0)$ & $100 \%(17)$ & 17 \\
$31-35$ & $35.3 \%(6)$ & $64.7 \%(11)$ & 17 \\
$36-40$ & $58.8 \%(10)$ & $41.2 \%(7)$ & 17 \\
$41-45$ & $88.2 \%(15)$ & $11.8 \%(2)$ & 17 \\
$46-50$ & $100 \%(17)$ & $0 \%(0)$ & 17 \\
$51-55$ & $100 \%(17)$ & $0 \%(0)$ & 17 \\
$56-60$ & $100 \%(17)$ & $0 \%(0)$ & 17 \\
\hline
\end{tabular}
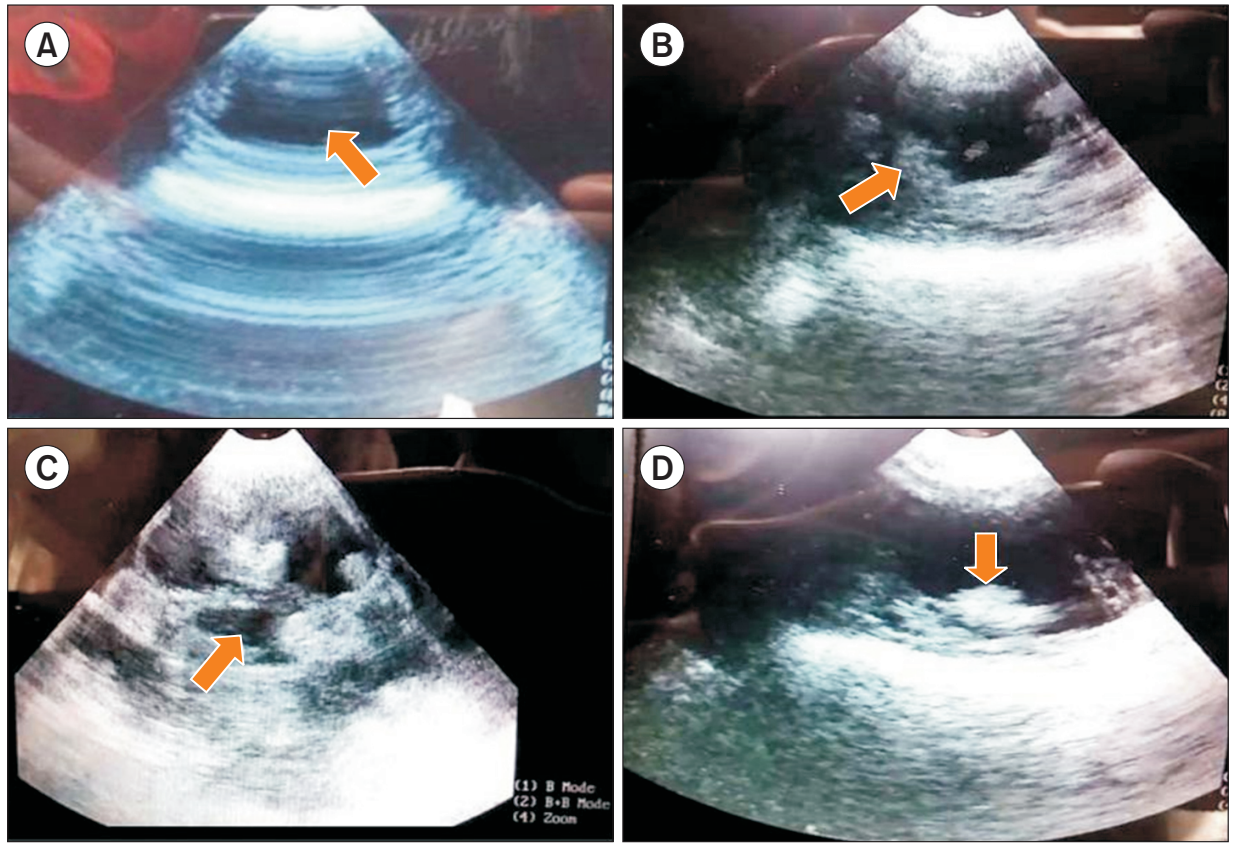

Fig. 2. Gestational sac at different days of gestation (A: Gestational sac below the bladder at 25 days after mating; B: Gestational sac with embryonic vesicles at 26 days after mating; C: Gestational sac at 28 days of gestation; D: Gestational sac with embryonic vesicle at 30 days after the mating). 
pregnancy. The frequency of detection of placentomes increased with the increase of gestation age and the percentage accuracy of detecting pregnancy was 52.9, 82.4 and $100 \%$ between $36-40$ days, $41-45$ days and $46-50$ days after mating respectively (Table 4 and Fig. 3).

\section{Leg buds}

Leg buds could not be detected till 36-40 days following mating. However, the detection of leg buds was first observed at 36-40 days in four does (23.5\%). The accuracy of pregnancy by detection of leg buds were 52.9, 76.5 and $100 \%$ between $41-45,46-50$ and 51-55 days respectively (Table 5 and Fig. 4).

\section{Vertebral column}

The vertebral column was detected in three does out of

Table 4. Percentage of pregnant does based on placentomes

\begin{tabular}{cccc}
\hline $\begin{array}{c}\text { Days after } \\
\text { mating }\end{array}$ & $\begin{array}{c}\text { Placentomes } \\
\text { observed }\end{array}$ & $\begin{array}{c}\text { Placentomes not } \\
\text { observed }\end{array}$ & Total \\
\hline $25-30$ & $0 \%(0)$ & $100 \%(17)$ & 17 \\
$31-35$ & $35.3 \%(6)$ & $64.7 \%(11)$ & 17 \\
$36-40$ & $52.9 \%(9)$ & $47.1 \%(8)$ & 17 \\
$41-45$ & $82.4 \%(14)$ & $17.6 \%(3)$ & 17 \\
$46-50$ & $100 \%(17)$ & $0 \%(0)$ & 17 \\
$51-55$ & $100 \%(17)$ & $0 \%(0)$ & 17 \\
$56-60$ & $100 \%(17)$ & $0 \%(0)$ & 17 \\
\hline
\end{tabular}
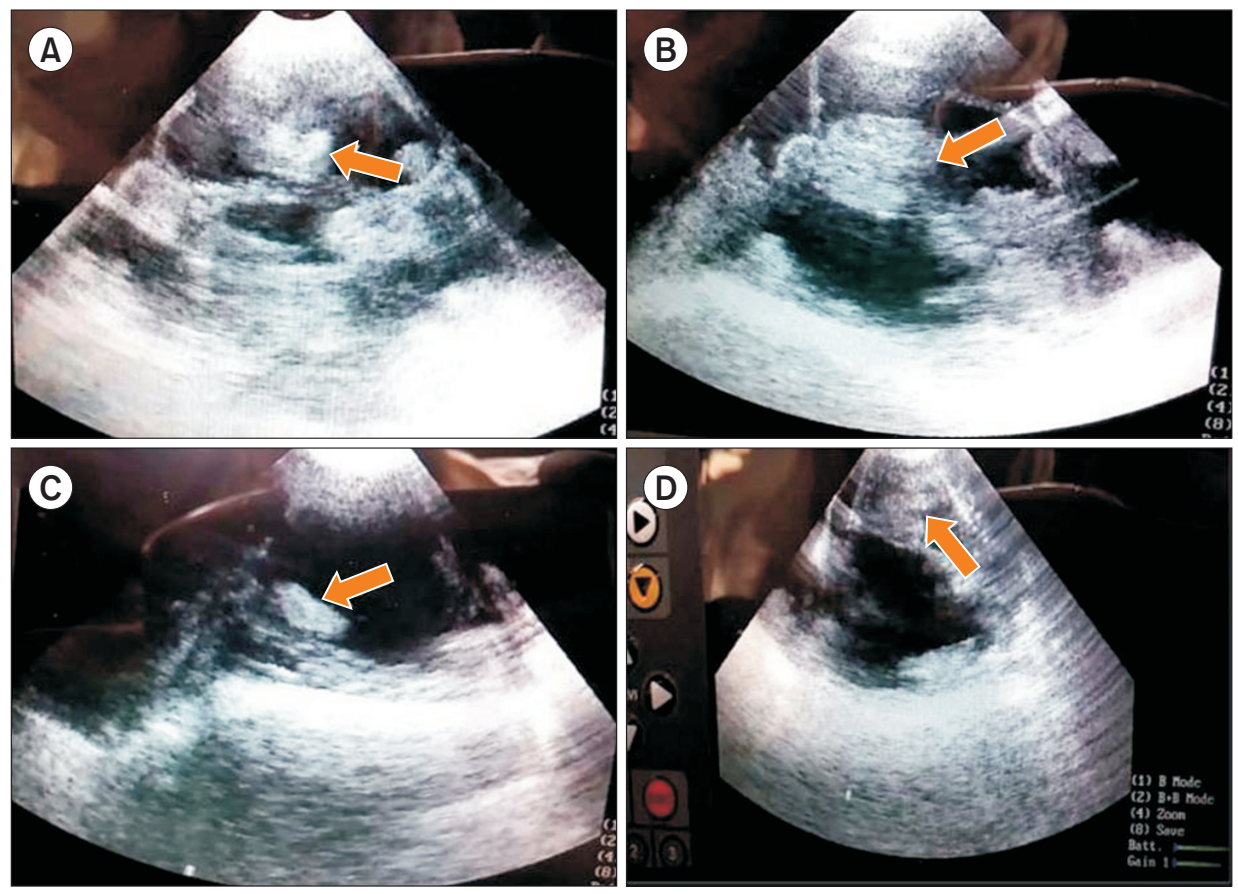

Fig. 3. Placentomes at different stages of gestation (Placentomes-A: at 31-35 days of gestation; $\mathrm{B}$ : at $36-40$ days of gestation; $C$ : at $41-45$ days of gestation; D: at 46-50 days of gestation). 
Table 5. Percentage of pregnant does based on observation of leg buds

\begin{tabular}{cccc}
\hline $\begin{array}{c}\text { Days after } \\
\text { mating }\end{array}$ & $\begin{array}{c}\text { Leg bud } \\
\text { observed }\end{array}$ & $\begin{array}{c}\text { Leg bud } \\
\text { not observed }\end{array}$ & Total \\
\hline $25-30$ & $0 \%(0)$ & $100 \%(17)$ & 17 \\
$31-35$ & $0 \%(0)$ & $100 \%(17)$ & 17 \\
$36-40$ & $23.5 \%(4)$ & $76.5 \%(13)$ & 17 \\
$41-45$ & $52.9 \%(9)$ & $47.1 \%(8)$ & 17 \\
$46-50$ & $76.5 \%(13)$ & $23.5 \%(4)$ & 17 \\
$51-55$ & $100 \%(17)$ & $0 \%(0)$ & 17 \\
$56-60$ & $100 \%(17)$ & $0 \%(0)$ & 17 \\
\hline
\end{tabular}

Table 6. Percentage of pregnant does based on observation of vertebral column

\begin{tabular}{cccc}
\hline $\begin{array}{c}\text { Days after } \\
\text { mating }\end{array}$ & $\begin{array}{c}\text { Vertebral column } \\
\text { observed }\end{array}$ & $\begin{array}{c}\text { Vertebral column } \\
\text { not observed }\end{array}$ & Total \\
\hline $25-30$ & $0 \%(0)$ & $100 \%(17)$ & 17 \\
$31-35$ & $0 \%(0)$ & $100 \%(17)$ & 17 \\
$36-40$ & $17.6 \%(3)$ & $82.4 \%(14)$ & 17 \\
$41-45$ & $41.2 \%(7)$ & $58.8 \%(10)$ & 17 \\
$46-50$ & $70.6 \%(12)$ & $29.4 \%(5)$ & 17 \\
$51-55$ & $82.4 \%(14)$ & $17.6 \%(3)$ & 17 \\
$56-60$ & $100 \%(17)$ & $0 \%(0)$ & 17 \\
\hline
\end{tabular}
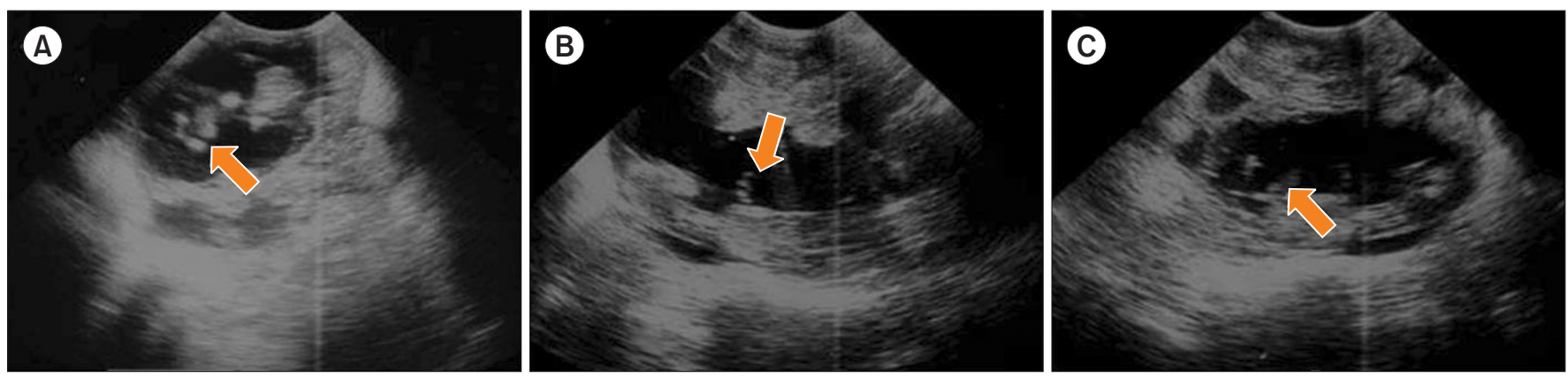

Fig. 4. Leg buds at different stages of gestation (A: at 31-35 days of gestation; B: 36-40 days of gestation; C: 41-45 days after mating).
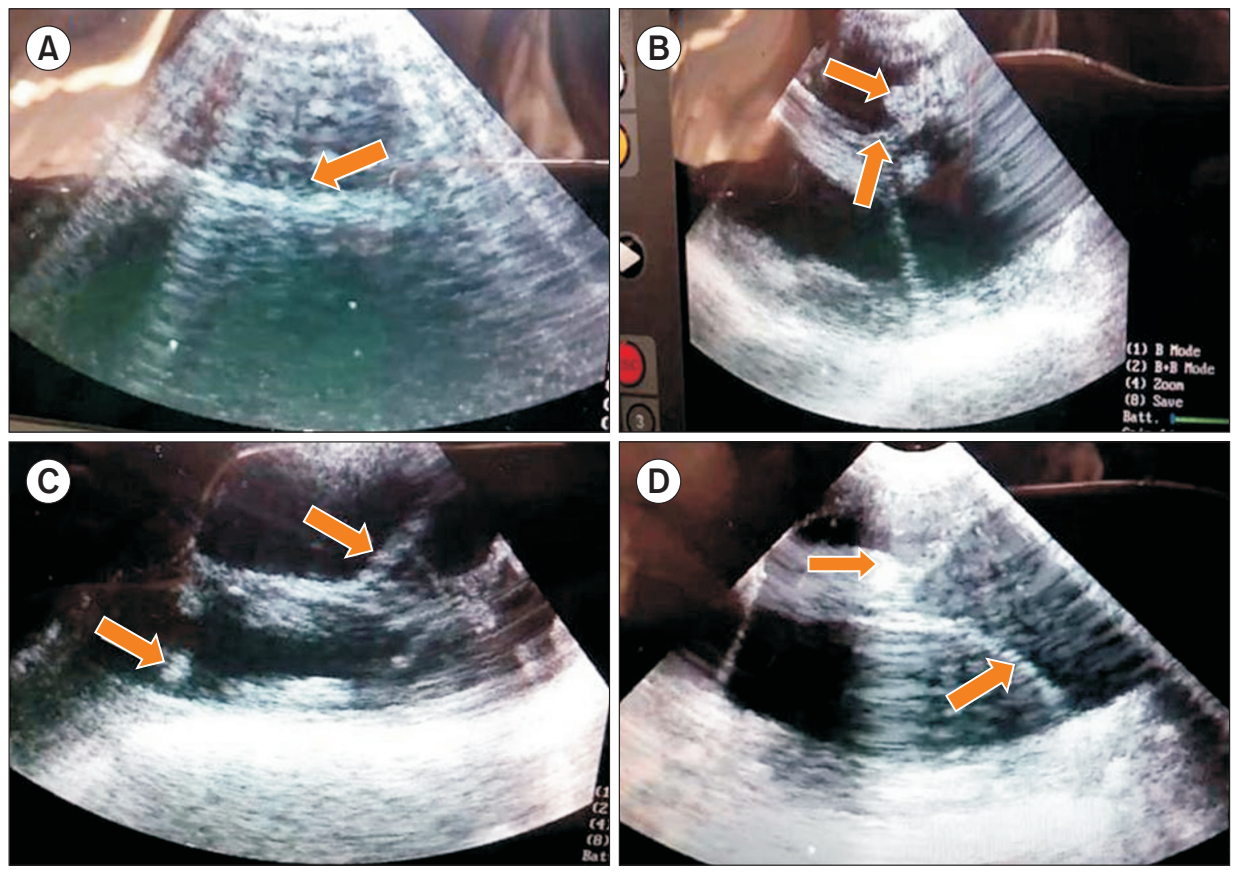

Fig. 5. Vertebral column at different stages of gestation (A: at 36-40 days of gestation; B: Vertebral Column and head of foetus at 41-45 days of gestation; C: at 51-55 days of gestation: D: Vertebral Column and heart of foetus at 56-60 days of gestation).

et al. (1972) observed that during the early stage of pregnancy of gestation length in does; there is an increase in intermediary cell numbers. Grant (1933) was also reported similar histological changes in vaginal mucosa during an- oestrus and pregnancy in goat.

Leigh et al. (2010) confirmed $83.3 \%$ pregnancy in does where there was sharp increase in superficial cells and clumping of epithelial cells. Only one doe (17.7\%) was 
not pregnant and this was the doe whose vaginal smear though showed similar pattern of exfoliated cells with others, was negative for sperm cells. Sharma (2016) reported various vaginal epithelial cells during early, mid and advanced stage of pregnancy in cows as $81.63,85.9$ and $88.23 \%$ of intermediate, $13.83,5.97$ and $4.53 \%$ of parabasal cells, $2.97,5.5,4.64 \%$ of superficial squamous and $1.57,2.55$ and $2.60 \%$ of cornified cells respectively which was more or less similar to our study except present of a few percentages of parabasal cells.

In the present study, the percentages of vaginal cells during early stages of pregnancy easily differentiated with percentages of vaginal cells during the stages of oestrous cycle of goats (Ola et al., 2006). Higher percentages of intermediate cells were found at early stages of pregnancy but in case of oestrous cycle few percentages were found.

\section{Real-time, B-mode ultrasonography}

1) Gestational sac

In the present investigation, the gestational sac, in the form of circular and elongated fluid filled anechogenic images located cranial to bladder was seen in only three does with $17.6 \%$ accuracy at 25 to 30 days after mating. The findings of current study are in accordance with Gearhart et al. (1988), Taverne et al. (1985) and Bretzlaff et al. (1993) who also reported that pregnancy could be first verified at 25 to 30 days after the breeding. No false positive cases were recorded in the present study. False positives results are rare and are attributed to the early embryonic death, unobserved abortion and sometimes misinterpreting the urinary bladder as the uterus (Fowler and Wilkins, 1984; White, 1984; Haibel et al., 1990).

\section{2) Foetal heart beat}

In the present study, heart beat was observed for the first time at 31-35 days of gestation in six does out of seventeen with $35.3 \%$ of accuracy. The heart beat became more prominent with the advancement of gestation and the rate of accuracy detected was $58.8,88.2$ and $100 \%$ at 36-40, 41-45 and 46-50 days of pregnancy, respectively.

The fetal heartbeat is one of the preferred indicators of pregnancy in does and ewes because it provides conclusive evidence of the presence of a live foetus (Aiumlamai, 1992; Amer et al., 2007). Similar observation have been reported where in fetal heart beats was determined clearly as early as 25 to 30 day of pregnancy and the foetus visu- alized by transrectal ultrasound (Oral et al., 2007). However, Aiumlamai et al. (1992) reported that fetal hearts in ewes were clearly seen at day 44 to 63 days of gestation and heart chambers and valves are distinguishable from day 97 to 103 of gestation by trans-abdominal ultrasonography. Further, the author also reported that the foetal heart rate reached a plateau by 7 weeks before lambing (167 \pm 1.5 beats per minute) and decreased to $139.0 \pm$ 15.7 and $117.0 \pm 9.2 \mathrm{bpm}$ at 3 weeks before and at lambing respectively.

\section{3) Placentomes}

In the present study, placentomes were detected with accuracy of $35.3,52.9,82.4$ and $100 \%$ at $31-35,36-40$, 41-45 and 46-50 days of pregnancy, respectively. Studies by Russel (1989) revealed that placentomes were identified from about day 40 as echoic circular structures in sheep. On day 42 , the ovine placentomes appears to be cup-shaped form and reaching the maximum size by day 74 (Doize et al., 1997). Placentomes were detected with $100 \%$ at $45-50$ days after the mating (Anwar et al., 2008). However, a poor correlation between placentomes size and ovine gestational age has been reported which was ascribed to great variation in the size of placentomes in different breeds (Doize, 1997; González et al., 1998). Hence, the finding of present study is in agreement with the previous reports that have also employed trans-abdominal ultrasonography using a $3.5 \mathrm{MHz}$ probe (Russel, 1989; Anwar et al., 2008).

\section{4) Foetal leg buds}

In the present study, the leg buds were first observed at 36-40 days of gestation only in four does with accuracy of $23.5 \%$ and was seen in all the seventeen does by $51-$ 55 days after the mating. Similar observations have also been reported previously by Anwar et al. (2008). It can be opined that the pregnancy diagnosis by trans-abdominal ultrasound based on foetal leg buds could be detected with $100 \%$ accuracy between 51 to 55 days of gestation.

\section{5) Vertebral column}

The vertebral column was first seen at 36-40 days of gestation and the percentage of accuracy of detecting foetal vertebral column increased with the advancement of gestation period. The pregnancy was detected in all the does by 55-60 days of gestation which is similar to the 
findings of Anwar et al. (2008). He confirmed that pregnancy diagnosis by trans-abdominal ultrasound based on vertebral column was done by 55-60 days of pregnancy with $100 \%$ accuracy.

\section{CONCLUSION}

The study concluded that vaginal cytology may be used for detection of pregnancy in doe. The real time transabdominal ultrasonography can be easily utilized for early pregnancy diagnosis in does at field level.

\section{CONFLICTS OF INTEREST}

No potential conflict of interest relevant to this article was reported.

\section{ACKNOWLEDGEMENTS}

The authors are grateful to the University Grants Commission of Bangladesh for financial support.

\section{AUTHOR CONTRIBUTIONS}

Conceptualization: Begum Fatema Zohara, Md. Aziz Ali

Data curation, Software and Formal analysis: Md. Aziz Ali, Md. Faruk Islam

Methodology: Begum Fatema Zohara, Md. Aziz Ali, Md. Faruk Islam, S M Latifur Rahman

Writing - original draft: Md. Aziz Ali

Writing - review and editing: Begum Fatema Zohara, Md. Faruk Islam

\section{AUTHOR'S POSITION AND ORCID NO.}

MA Ali, Researcher as MS Student, https://orcid.org/0000-0002-8611-6295

MF Islam, Professor as Research Co-supervisor, https://orcid.org/0000-0003-2331-0821

SML Rahman, Researcher as MS Student, https://orcid.org/0000-0001-8396-5104

BF Zohara, Professor as Research Supervisor, https://orcid.org/0000-0002-4101-5036

\section{REFERENCES}

Aiumlamai S, Fredriksson G, Nilsfors L. 1992. Real-time ultrasonography for determining the gestational age of ewes. Vet. Rec. 131:560-562.

Amer HA. 2007. Determination of first pregnancy and foetal measurements in Egyptian Baladi goats (Capra hircus). Vet. Ital. 44:429-437.

Amer HA. 2010. Ultrasonographic assessment of early pregnancy diagnosis, fetometry and sex determination in goats. Anim. Reprod. Sci. 117:226-231.

Anwar M, Riaz A, Ullah N, Rafiq M. 2008. Use of ultrasonography for pregnancy diagnosis in Balkhi sheep. Pak. Vet. J. 28:144-146.

Bretzlaff K, Edwards J, Forrest D, Nuti L. 1993. Ultrasonographic determination of pregnancy in small ruminants. Vet. Med. 88:12-24.

Doizé F, Vaillancourt D, Carabin H, Bélanger D. 1997. Determination of gestational age in sheep and goats using transrectal ultrasonographic measurement of placentomes. Theriogenology 48:449-460.

Faostat 2009. http://faostat3.fao.org/home/E.

Fowler DG and Wilkins JF. 1984. Diagnosis of pregnancy and number of foetuses in sheep by real-time ultrasonic imaging. I. Effects of number of foetuses, stage of gestation, operator and breed of ewe on accuracy of diagnosis. Livest. Prod. Sci. 11:437-450.

Gearhart MA, Wingfield WE, Knight AP, Smith JA, Dargatz DA, Boon JA, Stokes CA. 1988. Real-time ultrasonography for determining pregnancy status and viable fetal numbers in ewes. Theriogenology 30:323-337.

Ghannam SA, Bosc MJ, Du Mesnil du Buisson F. 1972. Examination of vaginal epithelium of the sheep and its use in pregnancy diagnosis. Am. J. Vet. Res. 33:1175-1185.

González de Bulnes A, Santiago Moreno J, López Sebastián A. 1998. Estimation of fetal development in Manchega dairy ewes by transrectal ultrasonographic measurements. Small Rumin. Res. 27:243-250.

González F, Cabrera F, Batista M, Rodríguez N, Alamo D, Sulon J, Beckers JF, Gracia A. 2004. A comparison of diagnosis of pregnancy in the goat via transrectal ultrasound scanning, progesterone, and pregnancy-associated glycoprotein assays. Theriogenology 62:1108-1115.

Grant R. 1933. Studies on the physiology of reproduction in the ewe. Trans. R. Soc. Edinburgh. 58:16-35.

Haibel GK. 1990. Use of ultrasonography in reproductive management of sheep and goat herds. Vet. Clin. North Am. Food Anim. Pract. 6:597-613.

Leigh OO, Raheem AK, Olugbuyiro JAO. 2010. Improving the reproductive efficiency of the goat: vaginal cytology and vulvar biometry as predictors of synchronized estrus/breeding time in West African dwarf goat. Int. J. Morphol. 28:923-928.

Matsas D. 2007. Pregnancy diagnosis in goats. In: Youngquist RS, Threlfall WR (Eds.), Current Therapy in Large Animal 
Theriogenology. 2nd ed, Saunders, Philadelphia, pp. 547554.

Ola SI, Sanni WA, Egbunike G. 2006. Exfoliative vaginal cytology during the oestrous cycle of West African dwarf goats. Reprod. Nutr. Dev. 46:87-95.

Oral H, Pancarcı SM, Gungor O, Kacar C. 2007. Determination of gestational age by measuring fetal heart diameter with transrectal ultrasonograph in sheep. Med. Weter. 63:15581560.

Russel AJF. 1989. The application of real-time ultrasonic scanning in commercial sheep, goats and cattle production enterprises. In: Taverne MAM, Willemse AH (Eds.), Diagnostic Ultrasound and Animal Reproduction. Kluwer Academic Publishers, Dordrecht, pp. 73-87.
Sharma M and Sharma N. 2016. Vaginal cytology: an historical perspective on its diagnostic use. Adv. Anim. Vet. Sci. 4:283288.

Talukder AK, Rahman MA, Hoque MN, Islam MT, Rahman ANMA, Das ZC. 2020. Conceptus-related measurements at early pregnancy in Black Bengal goat: an abattoir study. J. Anim. Reprod. Biotechnol. 35:177-182.

White IR, Russel AJ, Fowler DG. 1984. Real-time ultrasonic scanning in the diagnosis of pregnancy and the determination of fetal numbers in sheep. Vet. Rec. 115:140-143.

Zohara BF, Azizunnesa, Islam MF, Alam MGS, Bari FY. 2014. Exfoliative vaginal cytology and serum progesterone during the estrous cycle of indigenous ewes in Bangladesh. J. Emb. Trans. 29:183-188. 